\title{
Marine boundary layer over the subtropical southeast Pacific during VOCALS-REx - Part 1: Mean structure and diurnal cycle
}

\author{
D. A. Rahn and R. Garreaud \\ Departamento de Geofísica, Universidad de Chile, Santiago, Chile
}

Received: 6 November 2009 - Published in Atmos. Chem. Phys. Discuss.: 7 December 2009

Revised: 19 April 2010 - Accepted: 30 April 2010 - Published: 18 May 2010

\begin{abstract}
Atmospheric subsidence over the subtropical southeast Pacific (SEP) leads to a low-level anticyclonic circulation, a cool sea surface and a cloud-topped marine boundary layer (MBL). Observations in this region from a major field campaign during October and November 2008, the VOCALS Regional Experiment, provide ample data to characterize the lower atmospheric features over the SEP. The observations are also useful to test the ability of an area-limited, high-resolution atmospheric model to simulate the SEP conditions. Observations and model-results (where appropriate) improve the characterization of the mean state (Part 1) and variability (Part 2) of the lower troposphere including circulation, MBL characteristics and the upsidence wave.
\end{abstract}

Along $20^{\circ} \mathrm{S}$ the MBL is generally deeper offshore $\left(1600 \mathrm{~m}\right.$ at $\left.85^{\circ} \mathrm{W}\right)$ but there is also considerable variability. MBL depth and variability decrease towards the coast and maximum inversion strength is detected between $74-76^{\circ} \mathrm{W}$. Weather Research and Forecasting (WRF) simulations underestimate MBL height the most near the coast but improve offshore. Southeasterly trades prevail within the MBL although the wind speed decreases toward the coast. Above the MBL along the coast of Chile, flow is northerly, has a maximum at $3 \mathrm{~km}$, and extends westward to $\sim 74^{\circ} \mathrm{W}$, apparently due to the mechanical blocking exerted by the Andes upon the westerly flow aloft. Mean MBL features along northern Chile $\left(18-25^{\circ} \mathrm{S}\right)$ are remarkably similar (e.g., MBL depth just below $1 \mathrm{~km}$ ) in spite of different SST. Observed diurnal cycles of the temperature at the coast and further offshore exhibit a number of conspicuous features that are consistent with the southwestward propagation of an upsidence wave initiated during late evening along the south Peru coast. Furthermore, the passage of the vertical motion results

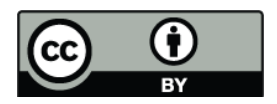

Correspondence to: D. A. Rahn (darahn@gmail.com) in either constructive or deconstructive interference with the radiatively-forced diurnal cycle of MBL depth. Interference is clearly seen in the soundings at Iquique which are driven by a strong upsidence wave contrary to the radiation-driven cycle, leading to a diurnal cycle opposite of the other sites. Because WRF simulations have a lower MBL height, the speed of the simulated gravity wave is slower than observations and accounts for most of the discrepancy between observed and simulated phase speeds.

\section{Introduction}

The region offshore of northern Chile and southern Peru exhibits the archetypical structure that characterizes the lowertroposphere of the eastern boundary of subtropical oceans. A surface anticyclone over the subtropical Southeast Pacific (SEP) is maintained by large-scale subsidence, producing dry, stable conditions and forcing alongshore equatorward flow at low levels that prevail year round (Garreaud and Muñoz, 2005). Wind-induced coastal upwelling cools the ocean surface, offsetting the high solar radiation in these latitudes (Rutllant et al., 2004). Cold sea surface temperatures and warm air aloft result in a cool, moist marine atmospheric boundary layer (MBL) separated from the free troposphere by a strong temperature inversion. The MBL is often topped by a shallow layer of stratocumulus (Sc) cloud. Indeed, the SEP is blanketed by the largest and most persistent deck of Sc in the world (Klein and Hartmann, 1993), thus playing a major role in the regional and global climate (Ma et al., 1996; Stephens, 2005, and references therein). The Andes Cordillera rises to more than $4500 \mathrm{~m}$ a.s.l. within $200 \mathrm{~km}$ of the coastline, which provides a sharp lateral boundary and contributes to an increased lower tropospheric stability, enhancing the Sc (Richter and Mechoso, 2006). The diurnal cycle of the clouds and free troposphere circulation is also particularly marked over the SEP (Garreaud and Muñoz,

Published by Copernicus Publications on behalf of the European Geosciences Union. 
2004; O'Dell et al., 2008; Wood et al., 2009). A high aerosol concentration is typically present in the coastal MBL (Bennartz, 2007) in sharp contrast with clean air farther offshore (Tomlinson et al., 2007) with a maximum in the Arica Bight (Painemal and Zuidema, 2009). Contributions to higher aerosol come from coastal copper smelters, power plants, and other anthropogenic activities along the ChilePeru coast (Huneeus et al., 2006) as well as natural sources such as volcanoes (Anders et al., 1998).

Given their common and unique features, the SEP is a natural laboratory for studying the coupled ocean-atmosphereland system on diurnal to inter-annual timescales. This region, however, is sparsely observed. In situ observations are largely restricted to a few meteorological stations along the coastal desert (including just one regular radiosonde station at Antofagasta, $23^{\circ} \mathrm{S}$ ), one weather station in the offshore island of San Felix $\left(27^{\circ} \mathrm{S}, 80^{\circ} \mathrm{W}\right.$, see details in Painemal et al., 2009), and one fully instrumented ocean buoy at $20^{\circ} \mathrm{S}$, $85^{\circ} \mathrm{W}$ (Whelan et al., 2009). Meteorological data has also been obtained in a handful of scientific cruises transecting the region (Garreaud et al., 2001; Bretherton et al., 2004; Kollias et al., 2004; Serpetzoglou et al., 2008; de Szoeke et al., 2009), but these records alone did not suffice for a comprehensive description of the SEP's lower troposphere.

The VAMOS Ocean-Cloud-Atmosphere-Land Study (VOCALS) is an international program that precisely targets the SEP region aiming at (i) improving the understanding and regional/global model representation of aerosol indirect effects on the clouds and (ii) eliminating systematic errors of coupled atmospheric-ocean general and regional circulation models in the region (Wood et al., 2006). To this end, a major regional experiment was carried out during October and November 2008 in northern Chile and southern Peru. The socalled VOCALS-REx included an unprecedented number of atmospheric and oceanographic measurements taken concurrently from five aircraft, two research vessels, and two land sites, as described in Wood et al. (2007).

In this work we take advantage of the multi-platform, multi-instrument VOCALS-REx datasets to describe the large-scale structure and variability of the lower-troposphere over the SEP with emphasis on the MBL depth. Depth is important for features such as liquid water path, decoupling, and propagation speed of gravity waves. Whenever applicable, previous observations were used to place the twomonth VOCALS-REx period in context. Further, the insitu observations and satellite products were complemented with results from a high resolution, two-month long simulation using the Weather and Research Forecast model (WRF, Skamarock, 2005). Our objective is threefold. First, a description of the lower tropospheric circulation and temperature structure is given to shed light on the coupled oceanatmosphere-land system. Second, our large-scale meteorological characterization of the SEP provides context to many of the mesoscale and microphysical studies ongoing in the frame of VOCALS. Finally, while the WRF results were used to enhance our meteorological description, comparison between modeled and observed quantities (e.g., MBL depth) and processes (e.g., diurnal cycle) serve as a hard test for the ability of WRF to simulate the weather in oceanic, subtropical regions. Discrepancies are identified and possible explanations are offered to help understand the impact of model biases.

Given the breadth of results, they are divided among two papers. In Part 1 (this paper) the mean structure and circulation of the atmosphere is documented, including their mean diurnal cycles. Part 2 focuses on the day-to-day fluctuation of the MBL and the variability is interpreted in terms of the synoptic forcing over the SEP region (Rahn and Garreaud, 2009). Structure of Part 1 is as follows. Section 2 presents a brief description of the subset of VOCALS-REx observations used in this study and the setup of the WRF simulations. In Sect. 3 the mean structure (time average and variance) of the MBL over the SEP during VOCALS-REx is described. Aircraft missions during the field campaign were mostly concentrated at $20^{\circ} \mathrm{S}$ from the coast up to about $85^{\circ} \mathrm{W}$, while enhanced radiosonde observations were performed along the coast (roughly at $71^{\circ} \mathrm{W}$ ). Observations along these zonal and meridional transects were compared and complemented with the all-SEP WRF results. In Sect. 4 the diurnal cycle of the MBL is documented using the land-site and shipborne observations and further interpreted using the various fields from the WRF simulation. Results are summarized in the fifth and final section.

\section{Data}

\subsection{Observations}

Measurements from a large variety of sources were obtained during the VOCALS-REx period extending from 15 October to 15 November 2008 as described in detail by Wood et al. (2007). Figure 1 shows the location where MBL top was detected during VOCALS-REx from radiosondes, launched at coastal stations or on ships, and from aircraft passing through the inversion layer. Radiosondes were launched at surface stations along the coast at Iquique $\left(20.2^{\circ} \mathrm{S}\right)$, Antofagasta $\left(23.6^{\circ} \mathrm{S}\right)$, Paposo $\left(25.0^{\circ} \mathrm{S}\right)$, and Santo Domingo $\left(33.7^{\circ} \mathrm{S}\right)$. Launch times varied among stations and are summarized in Table 1 . Arica $\left(18^{\circ} \mathrm{S}\right)$ is included as a land station since vertical profiles were obtained near here from the $\mathrm{C} 130$ and G1 planes during takeoff and landing in and out of Arica, one of which was usually within a few hours of 12:00 UTC.

The NOAA C130 flew 15 transects along $\sim 20^{\circ} \mathrm{S}$, some of them extending out to $86^{\circ} \mathrm{W}$, porpoising between $200 \mathrm{~m}$ and $4000 \mathrm{~m}$ a.s.l. High-resolution cloud top heights retrieved from the Wyoming Cloud Radar onboard the $\mathrm{C} 130$ were also used as a proxy of the MBL top. The DOE G1 does not have the range as the $\mathrm{C} 130$ and so measured closer to shore mainly along $18.5^{\circ} \mathrm{S}$. During the voyage of the $\mathrm{R} / \mathrm{V}$ Ron Brown 
Table 1. Average MBL depth for various times including the difference between 12:00 and 00:00 UTC, standard deviation, and launch times. All times in UTC and units in meters.

\begin{tabular}{lrrcccrl}
\hline & $00: 00$ & $12: 00$ & $12: 00-00: 00$ & $00: 00$ and 12:00 & $\sigma_{00: 00}$ and 12:00 & All & Launch Times \\
\hline José Olaya, $13-16^{\circ} \mathrm{S}$ & 867 & 880 & 13 & 873 & 186 & 860 & Variable \\
Arica, $18.5^{\circ} \mathrm{S}$ & - & 1041 & - & - & - & 1027 & Near 12:00 \\
Iquique, $20.2^{\circ} \mathrm{S}$ & 1083 & 1023 & -60 & 1053 & 154 & 1038 & Every 4h \\
Antofagasta, $23.6^{\circ} \mathrm{S}$ & 909 & 1034 & 125 & 972 & 177 & 971 & $00: 00$ and 12:00 \\
Paposo, $25^{\circ} \mathrm{S}$ & 918 & 1138 & 220 & 1028 & 201 & 1066 & $00: 00,12: 00,18: 00$ \\
Santo Domingo, $33.7^{\circ} \mathrm{S}$ & 564 & 597 & 33 & 581 & 476 & 581 & $00: 00$ and $12: 00$ \\
\hline
\end{tabular}

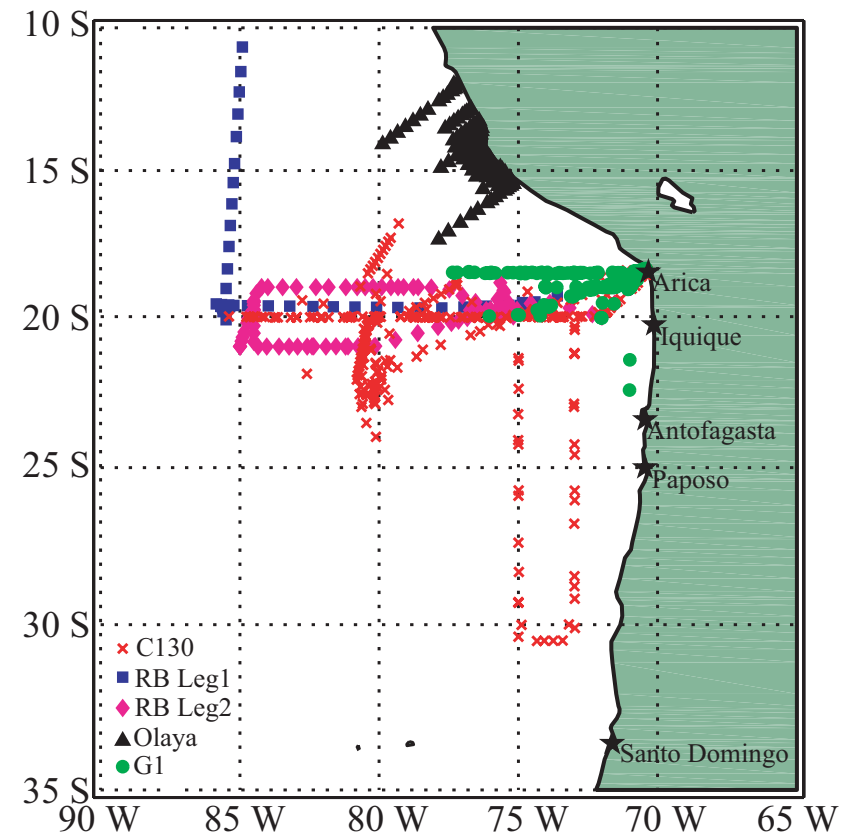

Fig. 1. Location of soundings from the R/V Ron Brown, R/V José Olaya, and land-based launch sites during VOCALS-REx (October-November 2008). C130 and G1 airborne observations indicate where the aircraft passed through the top of the MBL.

soundings were launched every four hours and totaled nearly 200. There were stationary periods at the Woods Hole buoy $\left(20^{\circ} \mathrm{S}, 85^{\circ} \mathrm{W}\right)$ and at the Dart Buoy $\left(20^{\circ} \mathrm{S}, 75^{\circ} \mathrm{W}\right)$. Additionally, the R/V José Olaya launched soundings from 5 to 17 October 2008 and was typically within a couple hundred kilometers of the central Peruvian coast in a fairly focused region $\left(13-16^{\circ} \mathrm{S}\right)$. The northern and southern transects from the $\mathrm{R} / \mathrm{V}$ José Olaya are excluded from analysis here since they reached farther offshore and were significantly different from the rest of the more clustered data near the shore.

Additional information is included from previous austral fall cruises (2001 and 2003-2007) in the SEP that also tended to focus on the $20^{\circ} \mathrm{S}$ transect with long stationary periods at the Woods Hole buoy. Cruises include those from the East Pacific Investigation of Climate in 2001 (Bretherton et al.,

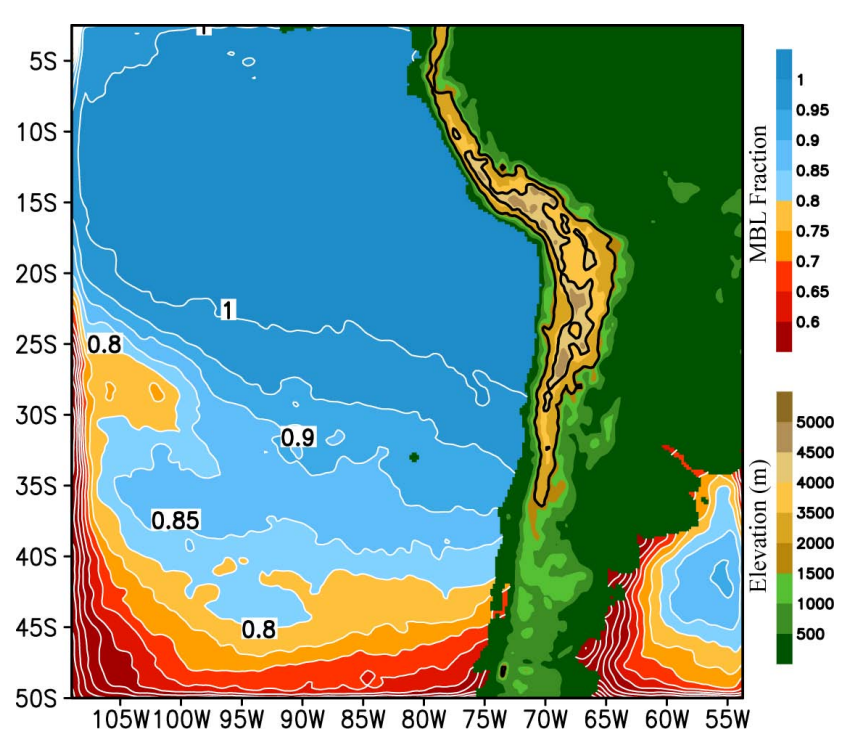

Fig. 2. WRF Domain showing terrain elevation ( $\mathrm{m}$, bottom color scale and black contours every $2000 \mathrm{~m}$ ) and fraction of time that a MBL was defined from WRF output (top color scale and white contours every 0.05 ).

2004), Stratus 2003 (Kollias et al., 2004), Stratus 2004 (Serpetzoglou et al., 2008), and Stratus 2007 (de Szoeke et al., 2009). Data is complied into the NOAA southeastern tropical Pacific synthesis data set, which provides an excellent resource for climate analysis and model assessment and is documented fully in de Szoeke et al. (2010).

\subsection{Numerical simulation}

In this work, we used the WRF model over a square domain with 280 grid points and 20-km horizontal grid spacing (Fig. 2). Vertical resolution consists of 44 sigma levels with telescoping resolution toward the surface $(\sim 10$-m resolution near the surface). The simulation was initialized on 1 October 2008 and run continuously for two months. Global Forecast System (GFS) analyses ( $1^{\circ}$ lat-lon grid) were used as initial and boundary conditions (updated every $6 \mathrm{~h}$ ). Parameterizations used for the run are the following: Thompson 
microphysics scheme, rapid radiative transfer model for the longwave radiation, the Dudhia shortwave radiation scheme, Monin-Obukhov (Janjic) surface scheme, Pleim land-surface model, Mellor-Yamada-Janjic boundary layer scheme, BettsMiller-Janjic cumulus scheme, second-order turbulence and mixing, and a horizontal Smagorinsky first-order closure eddy coefficient.

MBL depth from the output is calculated by finding the location of the temperature extrema and then selecting that with the lowest temperature below $3 \mathrm{~km}$. Since the minimum temperature is not necessarily at the base of the inversion, from this initial height where the minimum temperature is, each measurement above this height is checked until the temperature is found to be $0.5 \mathrm{~K}$ or higher than the minimum temperature, essentially moving up until the base of the inversion is found. The inversion is usually fairly strong so that this level is well-defined. The point under this threshold is defined as the MBL depth. MBL depth from this simple method has been inspected manually for quality control and works well to provide an objective height of the base of the temperature inversion.

In the model, the MBL is not always defined since there is not always a capping inversion (e.g., during the passage of a midlatitude front). Figure 2 shows the fraction of time that a MBL is present in the model. North of about $25^{\circ} \mathrm{S}$ the MBL is always defined. Toward the south the MBL is defined less frequently. Boundary effects along the southwest borders are visible but because the domain is large, influence of the boundary is negligible in the VOCALS region. When the MBL is undefined these times and locations are not used in subsequent calculations, filtering out events with large upward motion.

\section{Mean structure}

\subsection{Entire subtropical southeast Pacific}

Let us begin our description with an overall picture of the simulated MBL over the entire subtropical southeast Pacific and a qualitative comparison with satellite data. Figure 3a shows the all-time average of selected variables over the SEP region using WRF output. On average the simulated MBL depth (Fig. 3a) increases offshore with a broad maximum centered around $20^{\circ} \mathrm{S}, 100^{\circ} \mathrm{W}$. Overall the basic structure is similar to that inferred from satellite-based studies such as the September-October 2000 average (Wood and Bretherton, 2004), July 2006-June 2007 average (Leon et al., 2008), and October 2008 average (Zuidema et al., 2009). The simulated heights are, however, generally lower especially to the east of $75^{\circ} \mathrm{S}$. In the cross-shore direction, the MBL depth is loosely related to sea surface temperature (SST, Fig. 3a) such that higher SSTs are in general associated with higher MBL heights in agreement with results from Zuidema et al. (2009). In contrast, the MBL depth varies little along the coast in spite of more than $5^{\circ} \mathrm{C} \mathrm{SST}$ difference between central Chile and northern Peru.
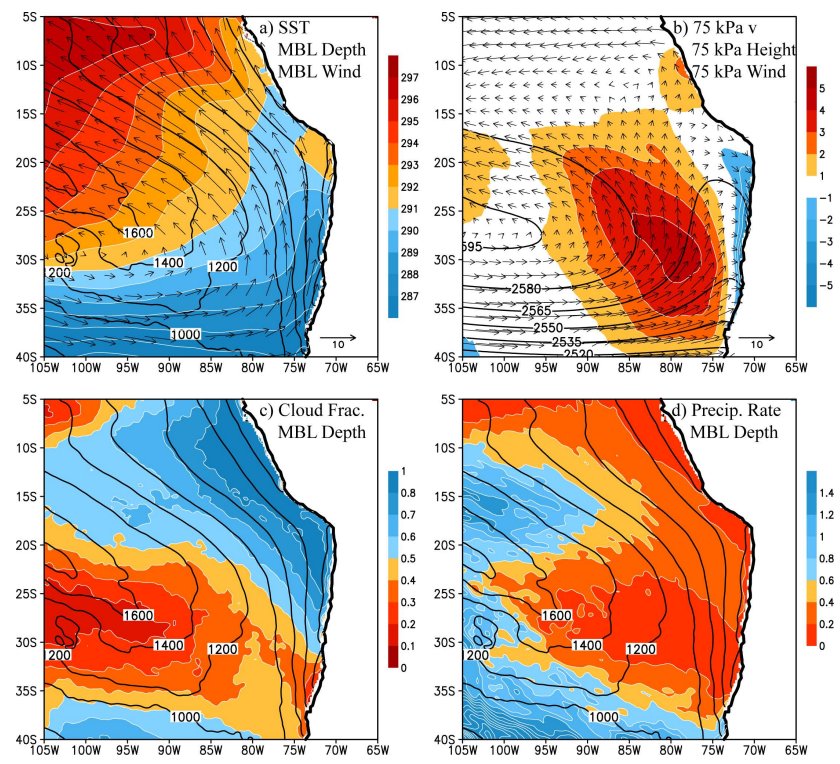

Fig. 3. October and November 2008 average of selected variables using the WRF simulation. (a) SST (K, color), MBL depth (m, contour), and wind at the top of the MBL (arrows, $\mathrm{m} \mathrm{s}^{-1}$ ), (b) $750 \mathrm{hPa}$ meridional wind component ( $\mathrm{m} \mathrm{s}^{-1}$, color), height ( $\mathrm{m}$, contour), and wind (arrows, $\left.\mathrm{m} \mathrm{s}^{-1}\right)$, (c) low $(<3 \mathrm{~km}$ ) cloud fraction (color) and MBL depth ( $\mathrm{m}$, contour), and (d) average precipitation rate (color, $\mathrm{mm} \mathrm{d}^{-1}$ ) and MBL depth ( $\mathrm{m}$, contour).

Winds within and at the top of the MBL are anticyclonic, associated with the typical near-surface high pressure distribution. Strong winds are found at the coast in central Chile associated with the coastal jet (Garreaud and Muñoz, 2005). Above the MBL at $750 \mathrm{hPa}(\sim 2.5 \mathrm{~km}$ a.s.1.) there is still anticyclonic flow over much of the SEP (Fig. 3b). Influence of the terrain is apparent since on average poleward flow prevails in a narrow band that extends from the coast to $74^{\circ} \mathrm{W}$ with largest values to the south of $20^{\circ} \mathrm{S}$. Observations later confirm these features.

Cloud and aerosol microphysics within numerical models can be difficult to simulate and may vary greatly from one model to another, not to mention the relationship with the observed fields (Myhre et al., 2007). Figure 3c depicts the temporal fraction of low cloud $(<3 \mathrm{~km})$ during October and November 2008. The overall picture is again consistent with cloud studies from satellites (e.g., Klein and Hartmann, 1993; Garreaud and Muñoz, 2005), including a maximum frequency off southern Peru, a broad minimum offshore nearly collocated with the deepest MBL and a more localized minimum off central Chile. Total accumulated precipitation over October and November 2008 (Fig. 3d) is small near the coast and increases offshore reaching a maximum around $15^{\circ} \mathrm{S}, 95^{\circ} \mathrm{W}$ due to the precipitating trade wind cumulus, which is also derived from satellites (Leon et al., 2008; Kubar et al., 2009). We have refrained from doing 

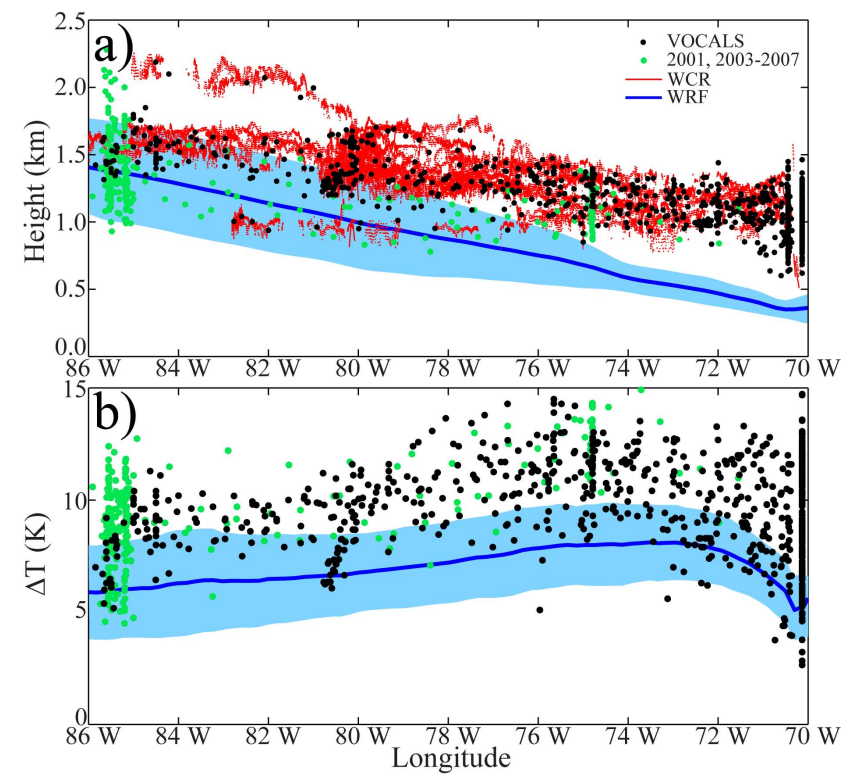

Fig. 4. Individual observations at $20^{\circ} \mathrm{S}$ of (a) the MBL height $(\mathrm{km})$ and (b) inversion strength (K) from VOCALS-REx (black dots), previous cruises (green dots), and Wyoming Cloud Radar (red lines). In both panels, the blue shading represents WRF values within \pm 1 standard deviation of the WRF 2-month average (solid blue line).

further characterization of the simulated cloud/precipitation properties until ongoing work using the VOCALS-REx dataset provides a more comprehensive observational picture for comparison.

\section{2 $20^{\circ} \mathrm{S}$ transect and alongshore $\mathrm{MBL}$ observations}

We now focus on the cross-shore (at $20^{\circ} \mathrm{S}$ ) and alongshore transects where VOCALS-REx data allows a more quantitative MBL description and estimate of the model performance. Figure 4a illustrates a cross section of the MBL depth within two degrees of $20^{\circ} \mathrm{S}$ from all available sources. Most of the data is from VOCALS-REx, but data from previous years is included as a reference. The two-month mean and standard deviation along $20^{\circ} \mathrm{S}$ from WRF is included to give a sense of the modeled MBL. Model and observations both show the upward sloping of the MBL depth from the coast westward. The deepest MBL $(\sim 1600 \mathrm{~m}$ a.s.l. $)$ is observed west of $80^{\circ} \mathrm{W}$, but this region in also characterized by high variability (see Part 2). Near the coast the average MBL depth is just over $1 \mathrm{~km}$ and there is less variability than offshore, suggesting a more consistent control of the MBL in the coastal region.

To the west of $80^{\circ} \mathrm{W}$ the simulated MBL depth is within the range of the observations (albeit about $200 \mathrm{~m}$ shallower than reality). The simulated depth, however, has an exaggerated decrease toward the coast so that near the shore the simulation underestimates the MBL height by about half. The simulated MBL depth is also particularly steady east of $74^{\circ} \mathrm{W}$. The underestimation of the MBL depth near the shore seems to pervade many numerical models (Hannay et al., 2009; Wyant et al., 2009) representing a major challenge for the modeling community.

Figure $4 \mathrm{~b}$ shows the inversion strength from WRF output and observations, simply calculated as the maximum minus the minimum temperature near the inversion. The model tends to underestimate this inversion strength, which is not surprising since it is difficult to represent such a strong vertical gradient in models even with relatively high vertical resolution. Agreement between model and observations tends to improve offshore and inversion strength increases from offshore to onshore until reaching a peak and diminishing again until the coastline, but the model peak appears to occur a couple degrees closer to shore.

Soundings along the coast at the various land stations are used to construct a mean state of the alongshore MBL structure. Examination of individual soundings from the $\mathrm{R} / \mathrm{V}$ José Olaya and the four land sites in northern Chile (Arica, Iquique, Antofagasta and Paposo) reveals a recurrent structure with a well defined MBL capped by a strong temperature inversion. An MBL exists at all times north of Santo Domingo. At Santo Domingo 7 of $62(11 \%)$ soundings did not have a clear MBL since the temperature inversion reached the surface. Distribution of MBL height from the land stations including all 00:00 UTC and 12:00 UTC soundings is shown in Fig. 5 (values $\leq 100$ represent no MBL), and the values of the mean and standard deviation are contained in Table 1. The MBL depth from Southern Peru down to Paposo tends to follow a normal distribution in a $600 \mathrm{~m}$ or so range. On average, the MBL is deepest (slightly over $1 \mathrm{~km}$ ) and relatively flat in the north of Chile between Paposo and Arica $\left(18.5-25^{\circ} \mathrm{S}\right)$ during this two month period. The coastal MBL around $15^{\circ} \mathrm{S}$ is shallower than observed farther south, probably in connection with intense, localized upwelling off the Pisco peninsula.

Santo Domingo $\left(33^{\circ} \mathrm{S}\right)$ soundings show MBL depth distributed over a greater range (with a positive skew) compared with stations farther north, attesting to the changes induced by mid-latitude systems. Profiles at Santo Domingo tend to contain a complicated structure, beyond that of a MBL, inversion, and free troposphere, making determination of the MBL depth more ambiguous. Despite this complexity, it is generally true that the MBL does tend to be shallower here than to the north with a mean MBL depth of $580 \mathrm{~m}$. Note that there is an $8^{\circ}$ gap between the northern soundings and Santo Domingo which may contain important structure between central Chile and the greater sampling in the northern region. 

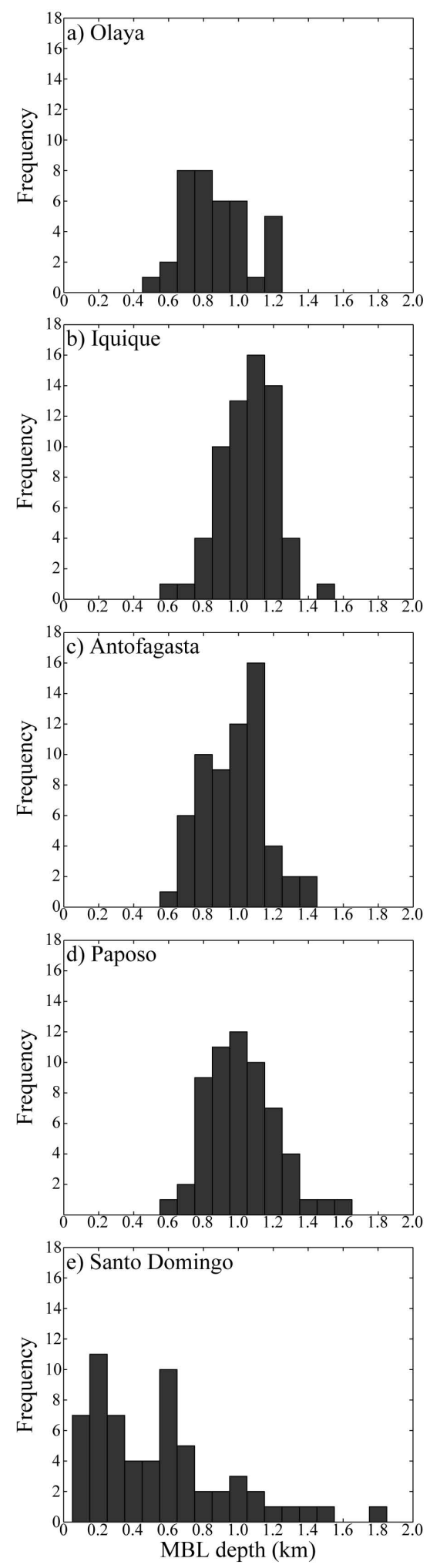

Fig. 5. Frequency of MBL depth for 100-m bins during VOCALSREx for the costal sites (a) R/V José Olaya $\left(\sim 15^{\circ} \mathrm{S}\right)$, (b) Iquique $\left(20.2^{\circ} \mathrm{S}\right)$, (c) Antofagasta $\left(23.5^{\circ} \mathrm{S}\right)$, (d) Paposo $\left(25^{\circ} \mathrm{S}\right)$, and (e) Santo Domingo $\left(33^{\circ} \mathrm{S}\right)$ using 00:00 and 12:00 UTC soundings.

\section{3 $20^{\circ} \mathrm{S}$ and alongshore mean cross sections}

Data from Iquique and all offshore soundings (including previous years) launched within two degrees of $20^{\circ} \mathrm{S}$ are used to construct mean profiles by binning the data every $1^{\circ}$ longitude and then contouring. The resulting cross section of potential temperature, zonal and meridional wind components are shown in Fig. 6. As seen before, the MBL is well defined and its depth tends to decrease towards the shore. Coldest temperatures within the MBL are contained between about $74^{\circ} \mathrm{W}$ and $78^{\circ} \mathrm{W}$ and are associated with the coolest average SST (Fig. 6c) as detected by the Advanced Very High Resolution Radiometer (AVHRR). This same range of longitudes exhibits warm air in the free troposphere thus producing the maximum inversion strength as detected in Fig. 4b. The upward sloping of the isentropes above $3 \mathrm{~km}$ between $\sim 73^{\circ} \mathrm{W}$ and the coast suggest reduced subsidence in the coastal strip due to the blocking effect of the inland terrain.

Flow within the MBL exhibits the SE trades in excess of $6 \mathrm{~m} \mathrm{~s}^{-1}$ to the west of $75^{\circ} \mathrm{W}$ but it diminishes rapidly toward the coast down to a $1 \mathrm{~m} \mathrm{~s}^{-1}$ southerly breeze. In contrast with this near stagnant condition within the coastal MBL, the above-inversion coastal wind exhibits an onshore wind up to $4 \mathrm{~m} \mathrm{~s}^{-1}$ and a poleward flow of 2-4 $\mathrm{m} \mathrm{s}^{-1}$. Observed magnitude and extent of this wind is consistent with the two month average of the simulated wind (Fig. 3b). While fewer observations exist in the near coast region, the ample observations at Iquique also show these features.

Let us now examine the alongshore variations using the mean profiles of the 00:00 and 12:00 UTC soundings at each location along the coast of Chile between $33.5^{\circ} \mathrm{S}$ to $18^{\circ} \mathrm{S}$ (Fig. 6b). The potential temperature cross section shows the southward cooling at mid-levels. Near the inversion level (around $1 \mathrm{~km}$ ) the isopleths diverge to the south since the soundings at Santo Domingo are more variable leading to a more uniform vertical distribution of potential temperature. Within the MBL the air is a couple degrees warmer in the north. At Santo Domingo the mean potential temperature is about $286 \mathrm{~K}$, while at Paposo it is about $288 \mathrm{~K}$ and at Iquique it is about $290 \mathrm{~K}$. Unfortunately there is a substantial gap in observations between $25^{\circ} \mathrm{S}$ and $33^{\circ} \mathrm{S}$ so how the MBL (specifically its depth and mean temperature) changes in this region is not known, but the AVHRR SST (Fig. 6d) suggests a gentle modification. It is also surprising that the MBL depth remains nearly level between $25-18^{\circ} \mathrm{S}$ despite a $\sim 2 \mathrm{~K}$ increase in SST and MBL mean temperature.

Zonal winds below $3.5 \mathrm{~km}$ are general very small (Fig. 6f) consistent with the blocking effect exerted by the coastal range and the Andes cordillera inland (average height about $4 \mathrm{~km}$ as indicated in Fig. 6f). Above $3.5 \mathrm{~km}$, the westerly flow increases dramatically. At Iquique there is a slight onshore $\left(1-2 \mathrm{~m} \mathrm{~s}^{-1}\right)$ component above the MBL $(\sim 1.5 \mathrm{~km})$ that is consistent with the $20^{\circ} \mathrm{S}$ cross sections, suggesting an extent of the onshore elevated breeze out to about $74^{\circ} \mathrm{W}$. The meridional wind component exhibits southerly winds in the 

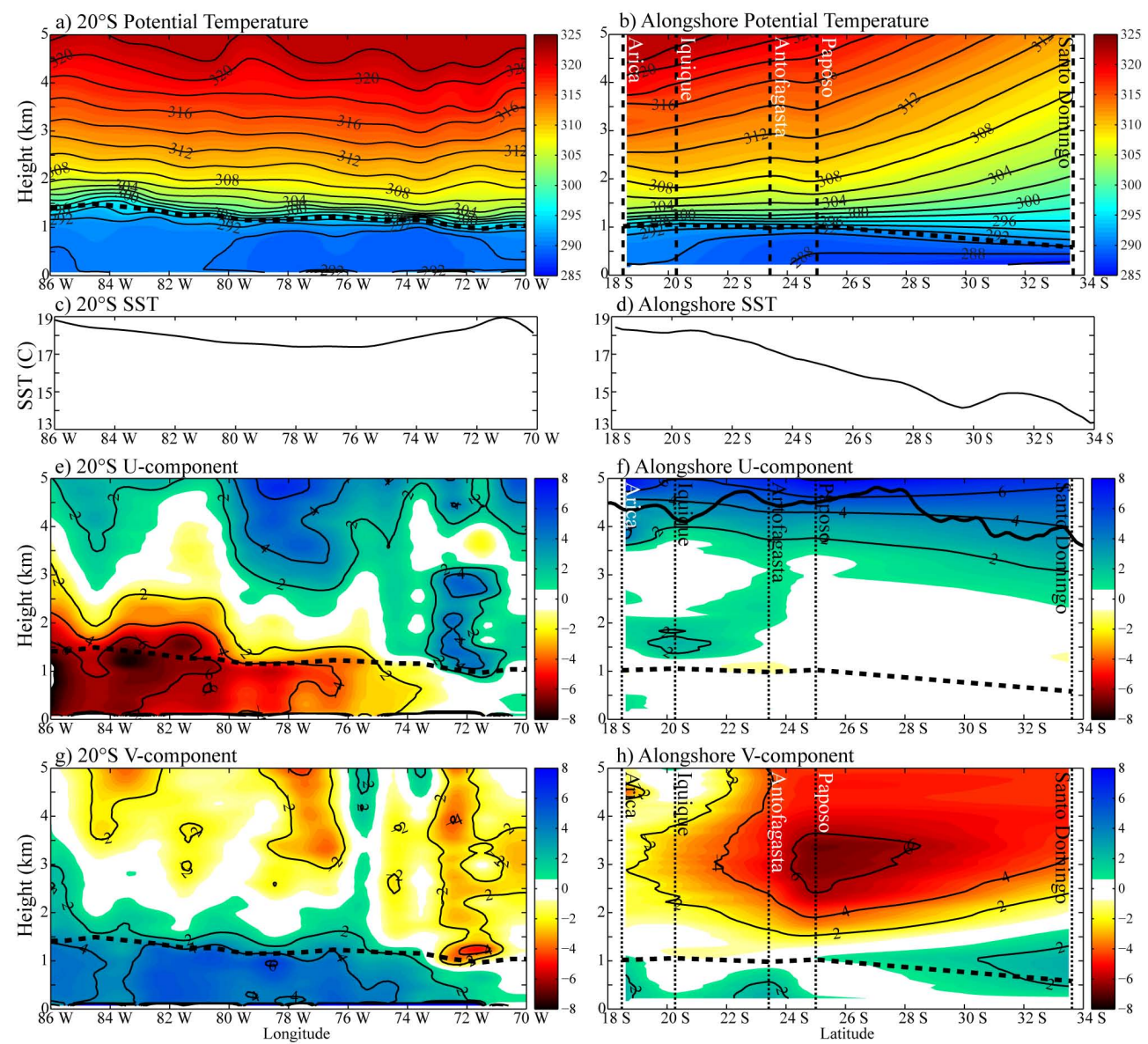

Fig. 6. Cross sections of soundings from the R/V Ron Brown along the $20^{\circ} \mathrm{S}$ transect (left column) and along the coast (right column). The variables are: $(\mathbf{a}, \mathbf{b})$ potential temperature $(\mathrm{K}),(\mathbf{c}, \mathbf{d})$ satellite-derived SST $\left({ }^{\circ} \mathrm{C}\right),(\mathbf{e}, \mathbf{f})$ zonal wind $\left(\mathrm{m} \mathrm{s}^{-1}\right)$, and $(\mathbf{g}, \mathbf{h})$ meridional wind $\left(\mathrm{m} \mathrm{s}^{-1}\right) . \quad 20^{\circ} \mathrm{S}$ uses all available data $(2001,2003-2008)$ and alongshore uses 00:00 and 12:00 UTC soundings from 15 October to 15 November 2008. In all panels, the thick dashed line shows the MBL mean depth. In panel (f) the thick solid line show the smoothed maximum topographic height.

lower troposphere and a strong northerly flow at mid-levels. The low-level southerlies maximize near Santo Domingo $\left(33^{\circ} \mathrm{S}\right)$ in connection with the coastal jet in that region (Muñoz and Garreaud, 2005). The mid-level northerlies encompass the entire cross section with a maximum of $6 \mathrm{~m} \mathrm{~s}^{-1}$ above Paposo near $3 \mathrm{~km}$. Such northerly flow has been previously documented by a handful of radiosondes near the Andes foothills in central Chile (Kalthof et al., 2002; Rutllant and Garreaud, 2004) and interpreted as a geostrophic response to a meso-high pressure over the Andean slope. Nevertheless, the coastal and offshore VOCALS-REx soundings together with our modeling results (Fig. 3b) indicates that such mid-level northerly flow extends at least $100 \mathrm{~km}$ off the coast thus playing an important role on the regional tropospheric transport.

\subsection{Model bias and possible implications}

A diagram similar to Fig. 6 is constructed using WRF output from 15 October to 15 November 2008 (Fig. 7). Along the coast only the 00:00 and 12:00 UTC soundings at each observational launch site are used. The cross section along $20^{\circ} \mathrm{S}$ uses all grid points. The most obvious difference is in the MBL height near the coast and the simulation has less stability at the top of the MBL. Lowest MBL temperatures are located 74 to $78^{\circ} \mathrm{W}$, similar to observations. The SST is similar, but the model has a slightly warmer SST near the coast likely because the model does not adequately resolve the narrow upwelling band right at the coast. Along $20^{\circ} \mathrm{S}$ the low-level wind speed is stronger by $\sim 2 \mathrm{~m} \mathrm{~s}^{-1}$ in the simulation consistent with the steeper slope of the MBL. Above the MBL the kinematic fields are similar with a northwest wind aloft extending west of the coast to $\sim 74^{\circ} \mathrm{W}$ and down to $\sim 1.5 \mathrm{~km}$, but the observations are noisier due to less sampling. Along the coast the kinematic structure is also similar 

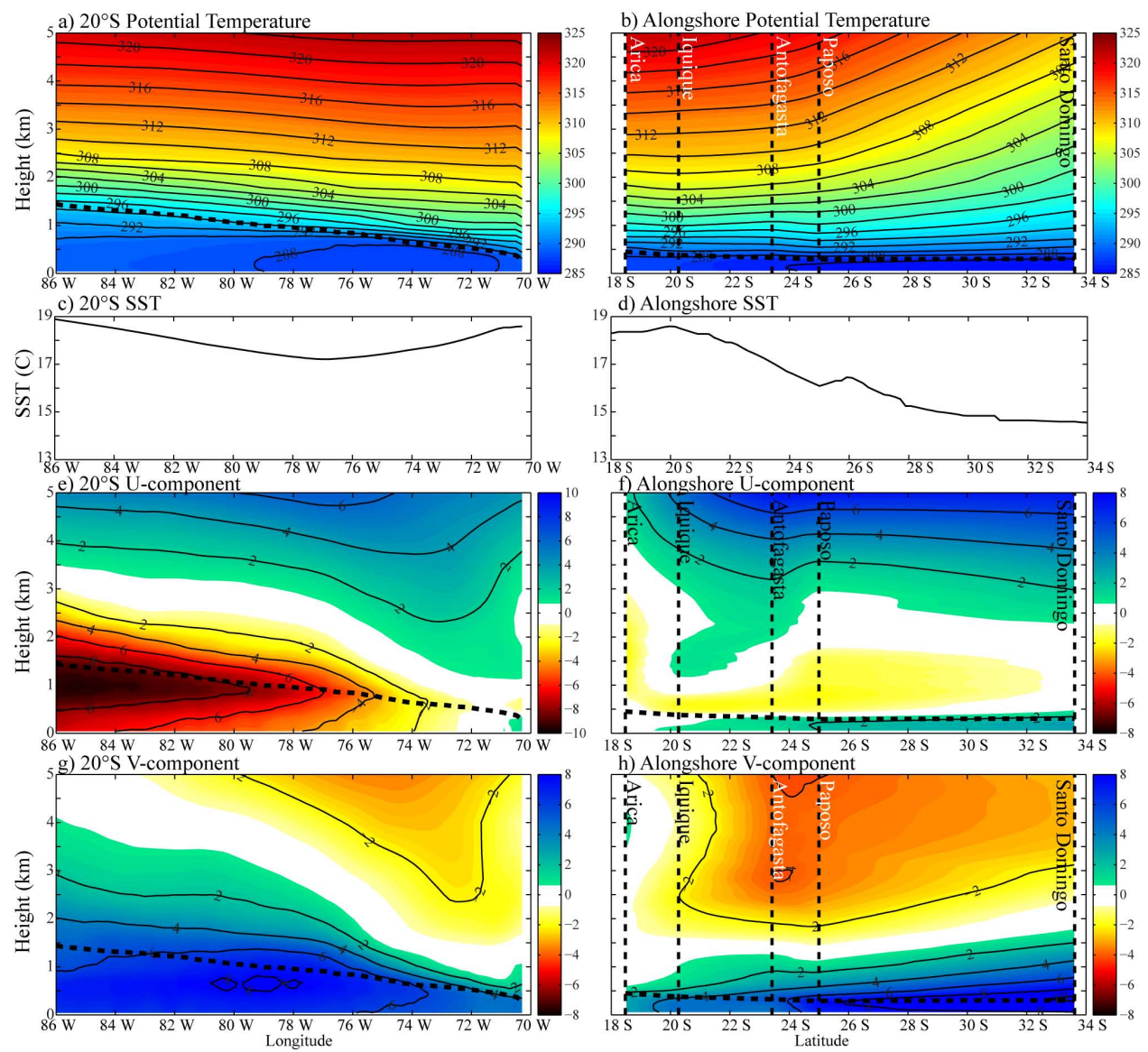

Fig. 7. Same as Fig. 6, but using WRF output.

aloft with a maximum of meridional wind above Paposo and Antofagasta at $\sim 2.5 \mathrm{~km}$. Clear differences are present below $2 \mathrm{~km}$. Soundings show no zonal wind component below $1 \mathrm{~km}$ while the simulation depicts a low-level onshore flow 1-2 m $\mathrm{s}^{-1}$ on average and a compensating offshore flow aloft.

Kinematic differences have generally been given less attention than MBL height differences, but they appear to have important implications that we now speculate on. Observations suggest that the high coastal terrain effectively blocks the intrusion of maritime air inland. Even soundings during the peak sea breeze show only a maximum average onshore wind near the surface of $<1 \mathrm{~m} \mathrm{~s}^{-1}$ and diminishing over the first few hundred meters. In contrast, model output depicts an onshore wind of $1-2 \mathrm{~m} \mathrm{~s}^{-1}$ both day and night. If the model allows greater low-level onshore flow, this would lead to enhanced low-level divergence and thus an MBL mass deficit in the simulation as compared to observations, which do not allow the cool maritime air to be ventilated up the Cordillera. While this divergence may appear small, if acting continually over a several hundred meters, it will have a large impact on the coastal MBL heights by lowering them.
A comparison between the average 10-m divergence from QuikSCAT and WRF during October and November 2008 highlights this difference (Fig. 8). While divergence is generally a noisy field, in the two month average there appears to be some systematic differences near the coast that confirm the conjecture that the larger simulated onshore flow is associated with a larger low-level divergence in the coastal region. Away from the coast west of $73^{\circ} \mathrm{W}$, the average divergence between $18-26^{\circ} \mathrm{S}$ is $2-3 \times 10^{-6} \mathrm{~s}^{-1}$. Entering the coastal region, the model and observations deviate greatly since QuikSCAT indicates a decrease of divergence to $\sim 0 \mathrm{~s}^{-1}$ near the coast and the model indicates a sharp increase up to $12 \times 10^{-6} \mathrm{~s}^{-1}$ right at the coast. Biases of $10-$ $\mathrm{m}$ wind divergence along all of the western coastlines using QuikSCAT data has previously been shown by McNoldy et al. (2004) who compared QuikSCAT wind to ECMWF and NCEP reanalysis data. They speculated that larger divergence at the coast in the analyses was likely due to greater onshore flow. We believe that this in turn impacts the MBL depth adjacent to the coast. Soundings from VOCALS-REx corroborate their results along the Chilean coast, and moreover, reveal that the biases in wind extend over a depth of a few hundred meters above the surface. 

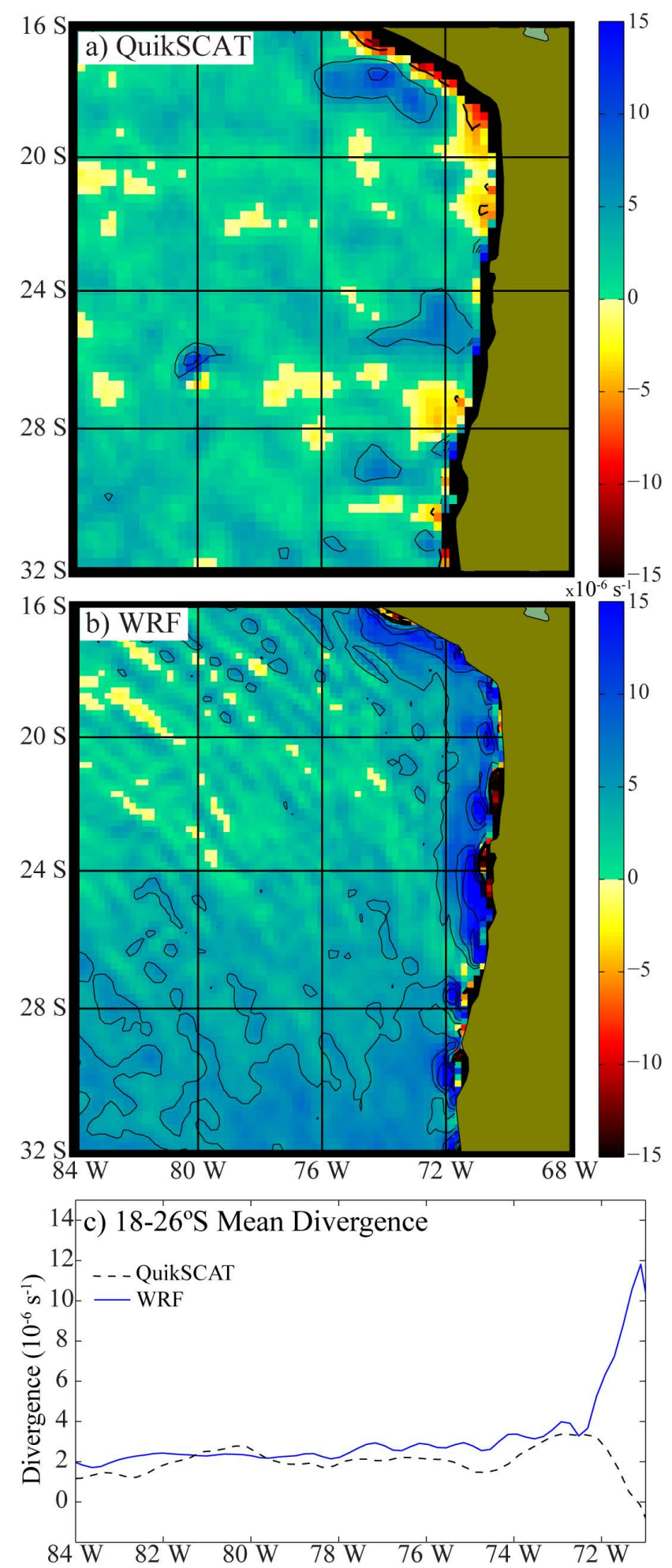

Fig. 8. Comparison of average 10-m divergence $\left(\times 10^{-6} \mathrm{~s}^{-1}\right)$ over October and November 2008 from (a) QuikSCAT, (b) WRF, and (c) mean divergence between $18-26^{\circ} \mathrm{S}$.
We hypothesize that the greater simulated onshore wind thins the MBL depth near the coast and the reason appears to stem from insufficient mechanical blocking at the coast. Less mechanical blocking at the coast may be a result of various factors including less stability at the coast that inadequately traps the MBL air or from something more fundamental with how the flow interacts with steep coastal terrain in the numerical simulation. Weaker stability could actually be a result of the enhanced circulation, but we cannot elaborate further at this time and leave this issue for future work.

\section{Diurnal cycle}

\subsection{Insights from WRF}

As commented in the introduction, satellite cloud climatologies reveal a particularly marked diurnal cycle over the SEP, including a prominent 6-h harmonic in LWP that cannot be attributed to the dominant 12-h harmonic of solar radiation (O'Dell et al., 2008; Wood et al., 2009). Based on numerical simulations over the SEP using the 5th generation Mesoscale Model (MM5), Garreaud and Muñoz (2004) identified a pulse of upward motion in the middle troposphere (the socalled upsidence wave) that detaches from the Peru coast in the early evening and could cause the complex, strong diurnal cycle in temperature and cloudiness in this region.

Our VOCALS-REx simulation using WRF also features a prominent upsidence wave. Figure 9 shows the mean diurnal cycle of vertical velocity anomalies (departures from the all-times mean) at $2.5 \mathrm{~km}$ every $3 \mathrm{~h}$. Note local standard time (LST) is UTC - 4 in Chile, UTC - 5 offshore to $82.5^{\circ} \mathrm{W}$, and UTC -6 from $82.5-97.5^{\circ} \mathrm{W}$, UTC -5 is used when multiple time zones are displayed. At 12:00 UTC (07:00 LST) the dominant mean subsidence is weakly perturbed by scattered anomalies of both signs. Over the next six hours downward motion intensifies, especially off northern Chile. Later in the day, a band of upward motion appears along the coast of Peru, reaching maximum intensity around 21:00 UTC (16:00 LST) and detaching from the coast by 00:00 UTC (19:00 LST) in a crescent-shaped area. As the upsidence wave travels into the SEP it begins to dissipate and leave the domain around 09:00 UTC (04:00 LST) substantially weakened. This WRF-based result is in excellent agreement with its MM5-based counterpart (Fig. 5 in Garreaud and Muñoz, 2004), despite the different model and simulation period.

A cross section of average diurnal perturbations along the direction of wave propagation is constructed to visualize the vertical extent, relation, and offshore propagation of various features (Fig. 10) of the upsidence wave. Beginning at 12:00 UTC (07:00 LST) vertical motion has only weak, positive anomalies, until 18:00 UTC (13:00 LST) when strong upward motion (U) develops near the coast. A cold anomaly (C1) at the MBL top develops at 21:00 UTC (16:00 LST) and 


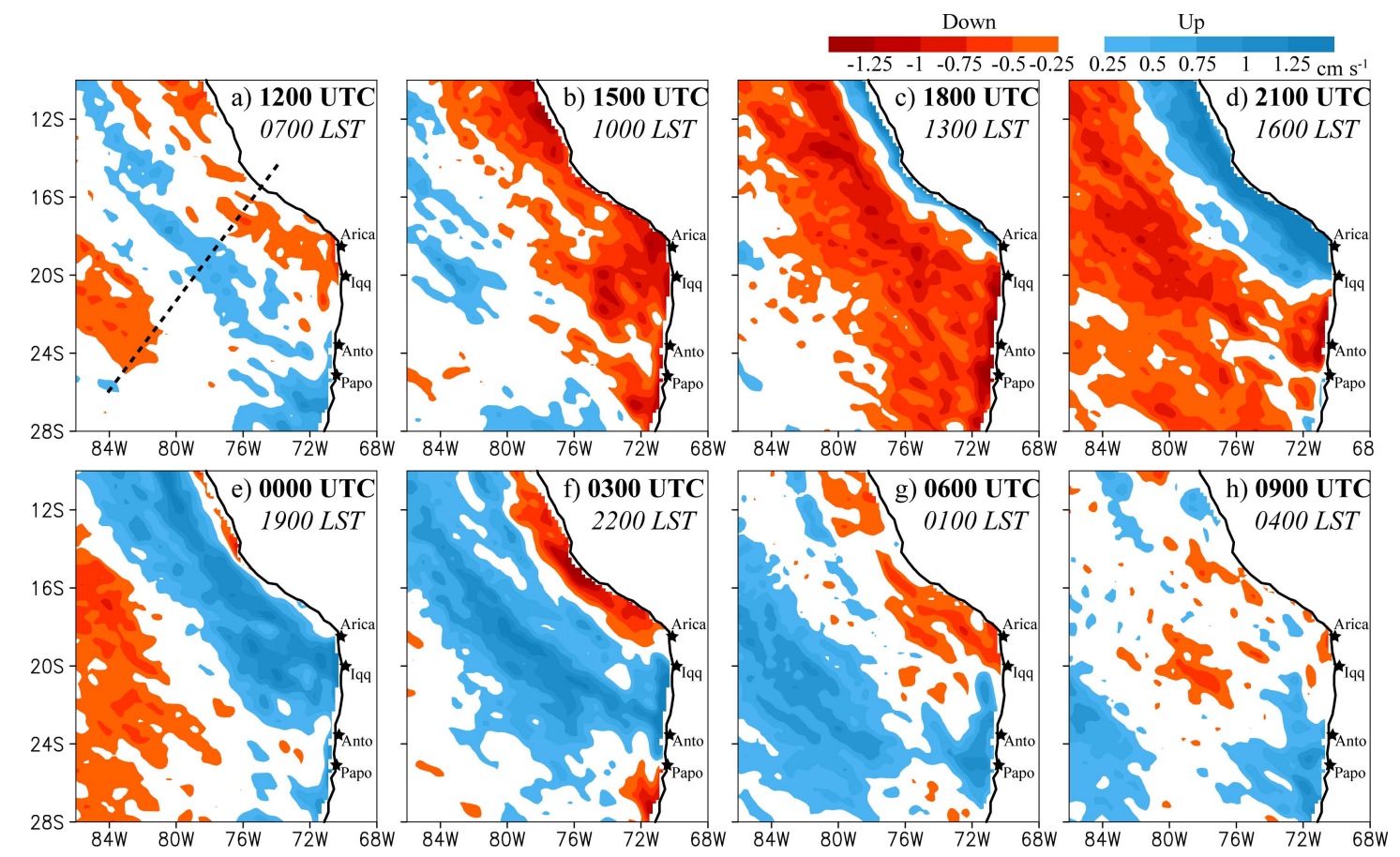

Fig. 9. WRF-simulated 2-month mean diurnal vertical velocity anomalies $\left(\mathrm{cm} \mathrm{s}^{-1}\right.$ ) at $2.5 \mathrm{~km}$ every 3 hours. Red (blue) indicates downward (upward) motion. Dashed line in (a) depicts location of subsequent cross section. Also shown is the location of the coastal sounding stations during VOCALS-REx.

is directly related to the upward motion. At 00:00 UTC upward motion increases, moves offshore, covers a more extensive horizontal region, and is mostly between 2 and $4 \mathrm{~km}$. Trailing the cold perturbation is a warm anomaly (W1) that, unlike the leading edge, is not associated with a strong vertical velocity anomaly aloft but in fact is under strong upward motion. After the vigorous upward motion aloft dissipates by 09:00 UTC (04:00 LST), the cold anomaly (C1) persists until becoming diffuse by 15:00 UTC (10:00 LST). The agreement in timing and position between the major vertical velocity and temperature anomalies is a natural consequence of the strongly stratified environment over the SEP (Garreaud and Muñoz, 2004), but it is worth noting that temperature anomalies can persist in absence of vertical velocity forcing.

\subsection{Observations}

We now use VOCALS-REx soundings to verify the existence of the upsidence wave mainly through its effect on temperature. Figure 11a shows the average 00:00 and 12:00 UTC temperature profiles emphasizing the uniform conditions between Paposo and Arica (Fig. 6b). The evening minus the early morning (00:00 UTC-12:00 UTC, 19:00 LST-07:00 LST) potential temperature profiles are shown in Fig. 11b. For every location, except for Iquique, the temperature shows warming aloft at 00:00 UTC (19:00 LST) in connection with a downward (upward) displacement of the inversion during daytime (nighttime). This sort of diurnal cycle in the near-shore MBL has been simulated and documented previously (e.g., Lilly, 1968; Blaskovic et al., 1991). In contrast, the Iquique sounding has a deeper boundary layer at the end of the day and its timing is coincident with the passage of the axis of the upsidence wave over Iquique that produces maximum upward motion at 00:00 UTC (19:00 LST, Fig. 9e).

The R/V Ron Brown had two stationary time periods during its transit along $20^{\circ} \mathrm{S}$, one at $85^{\circ} \mathrm{W}(25-27$ October) and one at $75^{\circ} \mathrm{W}$ (30 October-3 November). Figure 12 shows the time series of potential temperature anomalies (departure from the hourly mean) as well as the mean diurnal cycle of these anomalies. Because the time period is limited ( $\sim 3$ days), it is important to include the entire time series to demonstrate that there are no strong anomalies overshadowing a diurnal cycle. At $85^{\circ} \mathrm{W}$, there are strong anomalies at mid levels in the full time series (Fig. 12a), associated with synoptic-scale perturbations, but a weak diurnal cycle (Fig. 12b). The diurnal cycle in the MBL depth is about $350 \mathrm{~m}$ leading to strong changes in potential temperature near the inversion base. The MBL-depth cycle exhibits regular overnight (daytime) deepening (shallowing) as usually the case for stratocumulus capped MBLs (e.g., Lilly, 1968; Caldwell et al., 2005).

At $75^{\circ} \mathrm{W}$ the time series depicts a fairly clear diurnal cycle of potential temperature anomalies between two and three kilometers above sea level (Fig. 12c), readily evident in the 

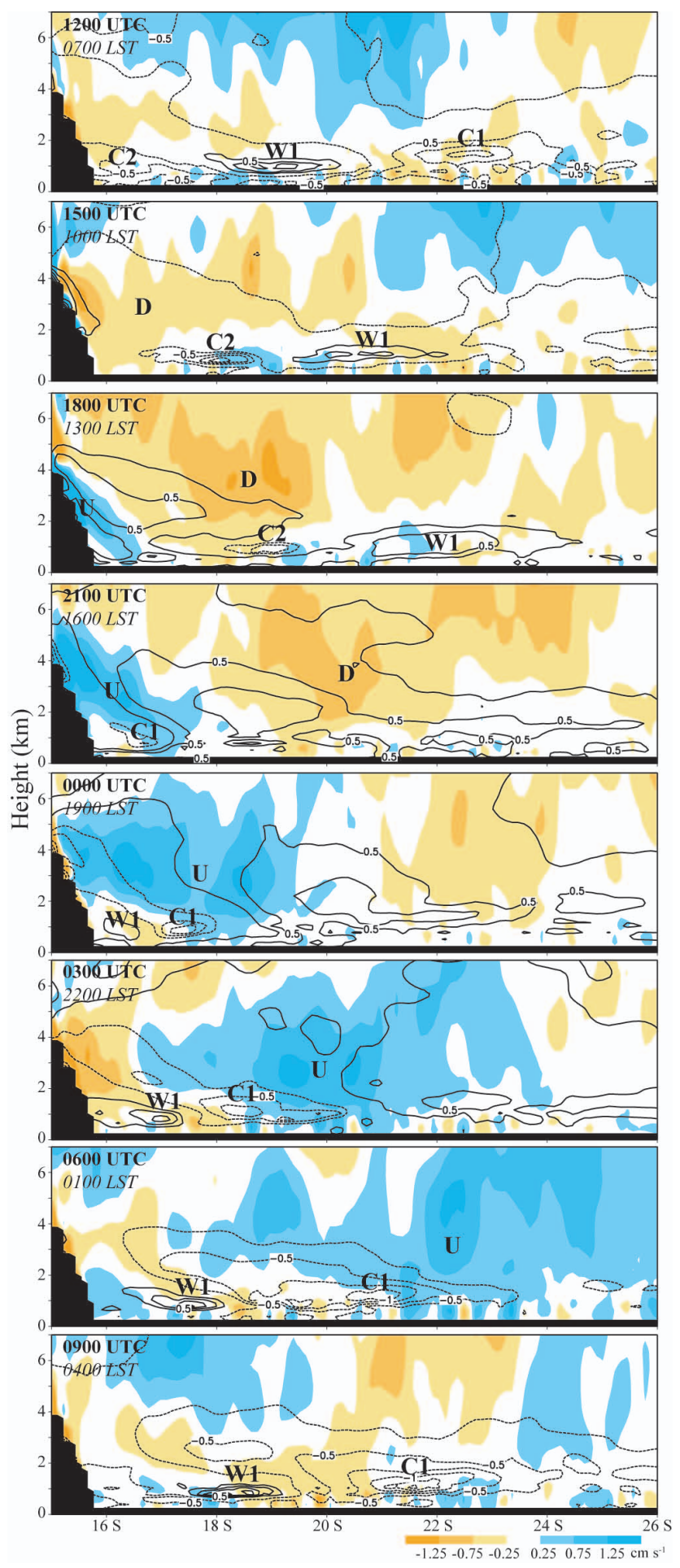

Fig. 10. WRF-simulated 2-month mean of hourly potential temperature anomalies (contours, $\mathrm{K}$ ) and vertical velocity anomalies (color fill; $\mathrm{cm} \mathrm{s}^{-1}$ ). The anomalies are shown in a cross-section extending southwest from Peru as depicted by the dashed line in the upper left plot of Fig. 7. Letters indicate (C1) the leading colder, deeper MBL anomaly, (W1) the warmer, shallower MBL, and (C2) the weaker trailing colder, deeper MBL. Letters indicate regions of (U) upward and (D) downward motion.
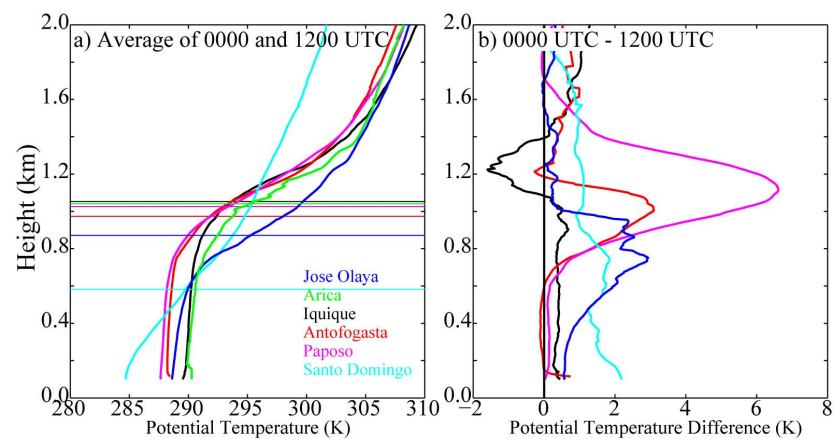

Fig. 11. (a) Average profile of potential temperature (K) for all 00:00 and 12:00 UTC coastal soundings during VOCALS-REx and (b) difference between average 00:00 UTC and average 12:00 UTC potential temperature profiles. Horizontal lines indicate the average MBL height.

average diurnal anomaly with a minimum near 05:00 UTC (00:00 LST) and a maximum near 20:00 UTC (15:00 LST, Fig. 12d). Notably, the amplitude of potential temperature diurnal cycle in the lower free troposphere is about $2 \mathrm{~K}$. The mean MBL depth varies $\sim 100 \mathrm{~m}$ during the day in a cycle that has a more complex structure than farther offshore. This cycle is readily seen in the diurnal potential temperature anomalies near the inversion base. The key feature is the abrupt and early demise of the daytime warming (MBL shallowing) about $3 \mathrm{~h}$ before local sunset in contrast with the evolution at $85^{\circ} \mathrm{W}$ where the "normal" warming demise occurs $\sim 3 \mathrm{~h}$ after sunset. Demise of the nighttime cooling at $75^{\circ} \mathrm{W}$ is also premature relative with the evolution at $85^{\circ} \mathrm{W}$. The warming-to-cooling transition atop of the MBL occurs in phase across much of the middle troposphere and is coincident with the onset of upward motion associated with the passage of the upsidence wave (blue arrow in Fig. 12d).

An illustration of the observed hourly potential temperature at $2.5 \mathrm{~km}$ above the surface for the two R/V Ron Brown sites is shown in Fig. 13. Warmest temperatures are at 18:00 and 03:00 UTC (13:00 and 22:00 LST) for $75^{\circ} \mathrm{W}$ and $85^{\circ} \mathrm{W}$, respectively. Coolest temperatures are at $03: 00$ and 15:00 UTC (22:00 and 10:00 LST) for $75^{\circ} \mathrm{W}$ and $85^{\circ} \mathrm{W}$, respectively. Peaks in the temperature correspond fairly well to the onset of the upward motion (cooling) and troughs in temperature correspond to the onset of downward motion (warming). If these peaks and troughs in temperature propagated along $20^{\circ} \mathrm{S}$ from $75^{\circ} \mathrm{W}$ to $85^{\circ} \mathrm{W}$ as coherent features, it takes between 6 and $9 \mathrm{~h}$ to move between the two locations traveling in a straight line $(1050 \mathrm{~km})$, resulting in a propagation speed between $32-48 \mathrm{~m} \mathrm{~s}^{-1}$. The upsidence wave propagates along a northeast to southwest axis (Fig. 9). Correcting the previous east-west propagation speed by $\sim \sin \left(45^{\circ}\right)$ results in a observational estimate of the upsidence wave phase speed of 23-34 $\mathrm{m} \mathrm{s}^{-1}$, in agreement with satellite data (Wood et al., 2009) and our model-based estimate $\left(30 \mathrm{~m} \mathrm{~s}^{-1}\right)$. 

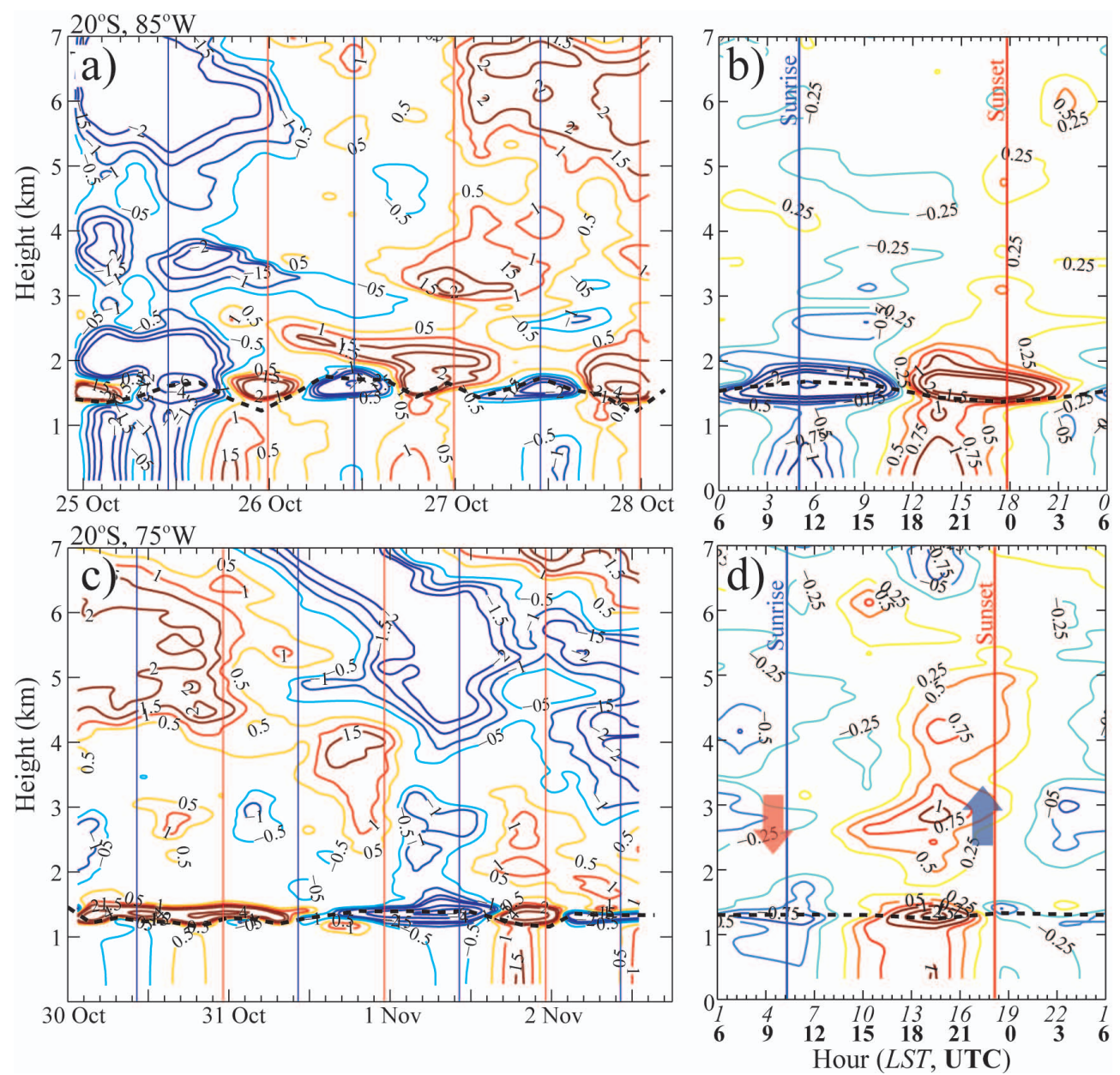

Fig. 12. Observed potential temperature anomalies from the mean state taken from R/V Ron Brown soundings during the stationary periods at $20^{\circ} \mathrm{S}, 85^{\circ} \mathrm{W}$ (upper panels) and $20^{\circ} \mathrm{S}, 75^{\circ} \mathrm{W}$ (lower panels). The anomalies are shown as a time series (a and $\mathbf{c}$ ) and as an average diurnal anomaly (b and $\mathbf{d}$ ). MBL depth is indicated by bold dashed line. Blue and red vertical lines indicate local sunrise and sunset, respectively. Arrows indicate vertical motion inferred from the WRF simulation.

\subsection{Model-observations discrepancies}

To further compare the observed and simulated diurnal cycles of temperature, Fig. 14 presents mean diurnal temperature anomalies for the observations (as in Fig. 12 but repeated over $48 \mathrm{~h}$ ), the WRF-simulated anomalies for the same time period as the observations, and the WRF-simulated anomalies for the entire two month period. While the two-month averages are more diffuse because they represent a greater range of conditions, model results from the subset time period and the entire two months are in agreement, indicating robust diurnal features. There is a fairly good agreement between the WRF and observations in the middle troposphere, both in the timing and amplitude of the diurnal cycle. Even the 2-month average of the model contains the four distinct potential temperature anomalies at the top of the MBL. The simulated 2-month period includes average diurnal perturba- tions in upward vertical motion by the shading and arrows that indicate the vertical motion that is acting as the mechanism for the rapid change in temperature.

Near the inversion base, however, the characteristics are not as well represented since a shallower MBL in the simulation is clearly evident, especially at the near shore R/V Ron Brown station $\left(20^{\circ} \mathrm{S}, 75^{\circ} \mathrm{W}\right)$. The simulation does capture the small, local temperature perturbations observed at the top of the MBL (four daily), but these anomalies are not at the same times (middle panels in Fig. 14). The major warm anomaly near the MBL top initiates at about 18:00 UTC (13:00 LST) in the observations and WRF. The following cold anomaly is at 00:00 UTC (19:00 LST) in the observations but occurs at 03:00 UTC (23:00 LST) in the simulation. These low-level model discrepancies are most likely a result of the shallower MBL depth. If these features at the MBL are initiated by the upward motion near the coast 


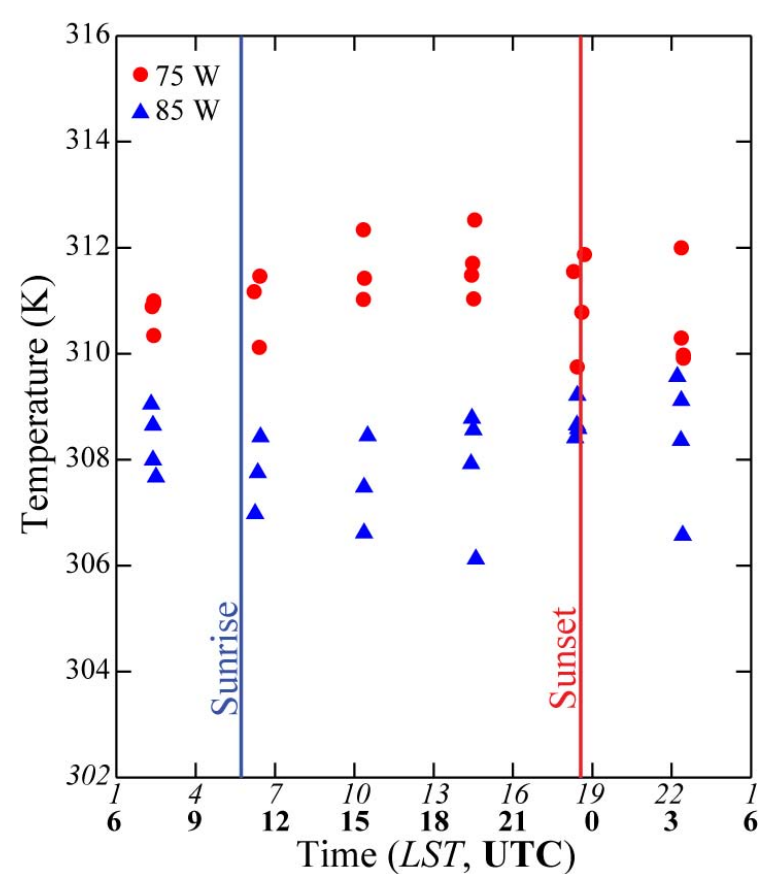

Fig. 13. Observed potential temperature $(\mathrm{K})$ at $2.5-\mathrm{km}$ for each day at which the R/V Ron Brown was stationed at $20^{\circ} \mathrm{S}, 75^{\circ} \mathrm{W}$ (circles) and $20^{\circ} \mathrm{S}, 85^{\circ} \mathrm{W}$ (triangles). Blue and red vertical lines indicate approximate local sunrise and sunset, respectively.

and propagate away from the shore as a gravity wave within the MBL, the speed of propagation is $c=\left(g^{\prime} H\right)^{1 / 2}$, where $g^{\prime}$ is reduced gravity and $H$ is MBL depth. Assuming a similar $g^{\prime}$ and wavelength between model and observations, the WRF-simulated gravity wave would have a phase speed 0.71 of the observed wave, since the simulated MBL depth is only half of the observed value. This slower propagation of the simulated gravity wave accounts for most of the delay in the onset of the cold anomalies atop the MBL at $20^{\circ} \mathrm{S}, 75^{\circ} \mathrm{W}$ relative to the observations.

\section{Summary}

Ample data over the subtropical Southeast Pacific obtained during the VOCALS-REx period (October-November 2008) has been used to characterize the mean state of the lower troposphere in this region, including circulation, temperature structure, MBL depth, and the impact of the upsidence wave in the diurnal cycle. The observations are largely clustered along a zonal transect at $20^{\circ} \mathrm{S}$ (from the coast to about $85^{\circ} \mathrm{W}$ ) and along the northern Chilean coast. A numerical simulation using the WRF model was run to expand upon observations and produced reasonable results including the distribution of cloud and drizzle when contrasted with satellite data. Direct comparison of the model MBL solution with observations, however, reveals model weaknesses near the coast. Several features of the SEP mean conditions are documented, including:
- Low-level anticyclonic circulation around the surface high pressure producing a trade wind $\sim 6 \mathrm{~m} \mathrm{~s}^{-1}$ offshore and much slower flow toward shore. Above the MBL there is still anticyclonic flow over the Pacific Ocean, but along the coast there is a north-northwest wind associated with anomalous high pressure along the topography induced by the blocking effect of the Andes cordillera. Model and observations both confirm the existence of a northerly barrier jet along the Andes with average poleward flow extending out to $\sim 74^{\circ} \mathrm{W}$ and maximum speed over $6 \mathrm{~m} \mathrm{~s}^{-1}$ above Paposo at $\sim 3 \mathrm{~km}$.

- Average MBL depth is $\sim 1600 \mathrm{~m}$ at $20^{\circ} \mathrm{W}, 85^{\circ} \mathrm{W}$ and decreases to $\sim 1000 \mathrm{~m}$ at the shore. Variability offshore is significantly larger offshore than onshore leading to either steeper or flatter gradients. The simulation has this same trend but the MBL depth near the shore is much lower (about half of the observed value). A minimum in SST is offshore near $76^{\circ} \mathrm{W}$ in contrast with the warmest air aloft, producing maximum inversion strength between $74-76^{\circ} \mathrm{W}$.

- Along the coast the average potential temperature within the MBL is cooler in the south, consistent with a SST decrease of $5 \mathrm{~K}$ from $18^{\circ} \mathrm{S}$ to $34^{\circ} \mathrm{S}$. Despite large changes in the SST, the MBL in northern Chile (18$25^{\circ} \mathrm{S}$ ) is fairly constant with a depth of about $1000 \mathrm{~m}$. At $33^{\circ} \mathrm{S}$, the MBL at Santo Domingo is generally lower than the other coastal stations, but the temperature profiles contain much larger variability due to being close to the mid-latitude storm tracks.

- While observations indicate minimal cross-shore wind, model output has a greater onshore flow near the surface and a compensating offshore flow aloft that is linked to greater low-level divergence along the coast. We speculate that the greater divergence in the coastal region stems from insufficient mechanical blocking by the steep topography and leads to an erroneous thinning of the MBL.

The diurnal cycle of temperature profiles obtained during VOCALS-REx exhibits several features that can be interpreted as the signature of the upsidence wave over the SEP, a regional-scale phenomena previously identified in modeling studies (Garreaud and Muñoz, 2004) and satellite-derived cloud analyses (O’Dell et al., 2008):

- All but one of the coastal soundings behaves as a typical cloud-topped MBL where the depth increases over night into the morning and decreases during the day. The exception is at Iquique where the MBL is deeper at the end of the day, attributed to the influence of the upward vertical motion shown by models to be directly over Iquique at this time. 

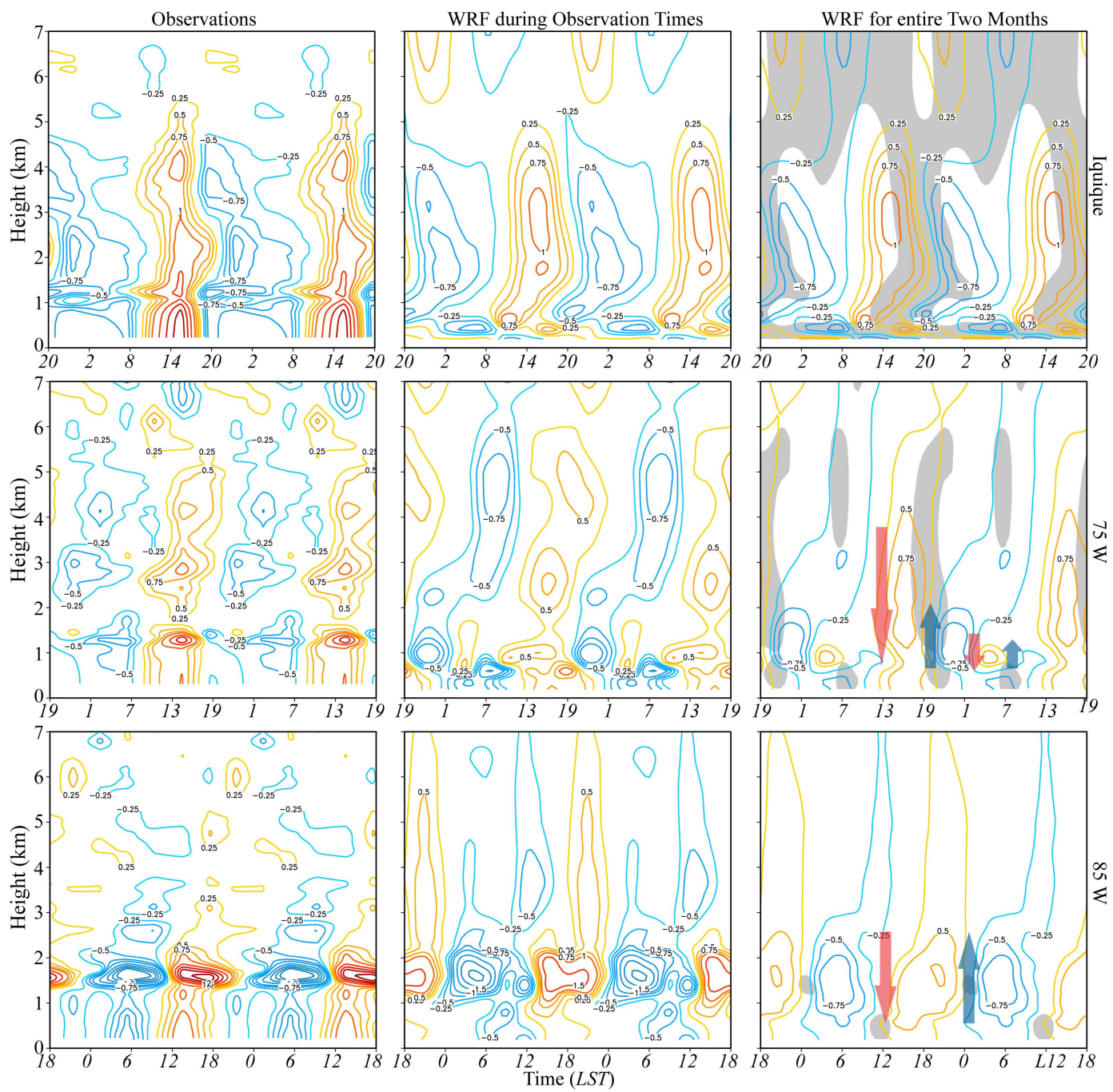

Fig. 14. Comparison of diurnal potential temperature anomalies (contour, K) from the mean state for (left) observations, (center) model simulation at time of observations, and (right) full two month simulation. Shading in the two month simulation figure (right) indicates average upward vertical velocity. The three locations depicted are at Iquique (top), $20^{\circ} \mathrm{S}, 75^{\circ} \mathrm{W}$ (center), and $20^{\circ} \mathrm{S}$; $85^{\circ} \mathrm{W}$ (bottom). Arrows indicate vertical motion.

- The stationary offshore observations taken onboard the $\mathrm{R} / \mathrm{V}$ Ron Brown have some conspicuous features. At $20^{\circ} \mathrm{S}, 75^{\circ} \mathrm{W}$ there is a damped, complicated MBL variation over the day, presumably because the normal radiative forcing and forcing from the subsidence wave are out of phase.

- At the same point and farther west $\left(20^{\circ} \mathrm{S}, 85^{\circ} \mathrm{W}\right)$ the potential temperature in the lower free troposphere (2$3 \mathrm{~km}$ ) exhibit a significant diurnal cycle (up to $2 \mathrm{~K}$ ) whose timing is very well explained by the alternation between positive and negative anomalies in the vertical velocity field created by the passage of the upsidence wave.

- There is an issue between model and observations with the timing of the perturbations at the top of the MBL at $75^{\circ} \mathrm{W}$, but this is explained by the difference in MBL height that impacts the propagation speed of a gravity wave. An underestimate in MBL depth by half produces a phase speed 0.7 slower. This highlights an important issue in that a correctly-simulated depth of the MBL is necessary to capture the precise diurnal cycle in the SEP near the coast.

While the mean MBL structure of the SEP has a well defined structure, especially in the east-west direction, our analyses reveal significant changes in the MBL depth offshore. In Part 2 of this work we use observations and the WRF simulation to (i) document these day-to-day changes, (ii) diagnose their forcing and ultimately (iii) connect them with the extratropical synoptic activity. 
Acknowledgements. This project was funded by the FONDECYT Grant 1090412 and CONICYT Grant ACT-19/R-19. We are very grateful to the numerous participates in VOCALS-REx that took observations. Soundings from the R/V Ron Brown over the years were compiled by Simon de Szoeke into the Tropical Eastern Pacific Stratocumulus Synthesis Data Set and were obtained with help from many crew and scientists onboard. The sounding systems in Iquique and on the R/V Jose Olaya were supplied by NCAR/EOL with the sponsorship of the U.S. National Science Foundation (NSF). Special thanks are due to Rosalino Fuenzalida, fellow staff and students at Universidad Arturo Prat, Iquique, Chile; and to Yamina Silva and Boris Dewitte at Instituto Geofísico del Perú, and Carmen Grados and colleagues at Instituto del Mar del Peru, and the officers and crew of the R/V Jose Olaya, Peru. Paposo soundings and the operational soundings at Antofagasta and Santo Domingo were operated by the Dirección Meteorológica de Chile lead by Jorge Carrasco with help from many staff and students. The G-1 is operated by Pacific Northwest National Laboratory's Airborne Facility and Programs Office. The NSF/NCAR C-130 is operated by the Research Aviation Facility at NCAR and University of Wyoming personnel provided radar-derived cloud top heights from the C-130 supported by NSF grant AGS-0715077.

Edited by: R. Wood

\section{References}

Anders, R. J. and Kasgnoc, A. D.: A time averaged inventory of subaerial vulcanic sulfur emissions, J. Geophys. Res., 103, 25251-25261, 1998.

Bennartz, R.: Global assessment of marine boundary layer cloud droplet number concentration from satellite, J. Geophys. Res., 112, D02201, doi:10.1029/2006JD007547, 2007.

Blaskovic, M., Davies, R., and Snider, J. B.: Diurnal variation of Marine Stratocumulus over San Nicolas Island during July 1987, Mon. Weather Rev., 119, 1469-1478, 1991.

Bretherton, C. S., Uttal, T., Fairall, C. W., Yuter, S. E., Weller, R. A., Baumgardner, D., Comstock, K., Wood, R., and Raga, G. B.: The EPIC 2001 stratocumulus study, B. Am. Meteorol. Soc., 85, 967-977, 2004.

Caldwell, P., Bretherton, C. S., and Wood, R.: Mixed-layer budget analysis of the diurnal cycle of entrainment in southeast Pacific stratocumulus, J. Atmos. Sci., 62, 3775-3791, 2005.

de Szoeke, S., Fairall, C. W., and Pezoa, S.: Ship observations coasting South America in the tropical Pacific Ocean, J. Climate, 22, 458-464, 2009.

de Szoeke, S., Fairall, C. W., Wolfe, D. E., Bariteau, L., and Zuidema, P.: Surface flux observations on the southeastern tropical Pacific Ocean and attribution of SST errors in coupled oceanatmosphere models, J. Climate, in press, 2010.

Garreaud, R. D., Rutllant, J., Quintana, J., Carrasco, J., and Minnis, P.: CIMAR-5: A snapshot of the lower troposphere over the subtropical southeast Pacific, B. Am. Meteorol. Soc., 82, 21932207, 2001.

Garreaud, R. D. and Muñoz, R. C.: The Diurnal Cycle in Circulation and Cloudiness over the Subtropical Southeast Pacific: A Modeling Study, J. Climate, 17, 1699-1710, 2004.
Garreaud, R. D. and Muñoz, R. C.: The low-level jet off the subtropical west coast of South America: Structure and variability, Mon. Weather Rev., 133, 2246-2261, 2005.

Hannay, C., Williamson, D., Hack, J., Kiehl, J., Olson, J., Klein, S., Bretherton, C., and Kohler, M.: Evaluation of forecasted simulated southeast Pacific stratocumulus in the NCAR, GFDL, and ECMWF models, J. Climate, 22, 2871-2889, 2009.

Huneeus, N., Gallardo, L., and Rutllant, J. A.: Offshore transport episodes of anthropogenic sulfur in northern Chile: Potential impact on the stratocumulus cloud deck, Geophys. Res. Lett., 33, L19819, doi:10.1029/2006GL026921, 2006.

Kalthoff, N., Bischoff-Gauß, I., and Fiebig-Wittmaack, M., and coauthors: Mesoscale wind regimes in Chile at $30^{\circ} \mathrm{S}$, J. Appl. Meteorol., 41, 953-970, 2002.

Klein, S. A. and Hartmann, D. L.: The seasonal cycle of low stratiform clouds, J. Climate, 6, 1587-1606, 1993.

Kollias, P., Fairall, C. W., Zuidema, P., Tomlinson, J., and Wick, G. A.: Observations of marine stratocumulus in the SE Pacific during the PACS 2003 cruise, Geophys. Res. Lett., 31, L22110, doi:10.1029/2004GL020751, 2004.

Kubar, T. L., Hartmann, D. L., and Wood, R.: Understanding the importance of microphysics and macrophysics for warm rain in marine low clouds. Part I: Satellite observations, J. Atmos. Sci. 66, 2953-2972, 2009.

Leon, D. C., Wang, Z., and Liu, D.: Climatology of drizzle in marine boundary layer clouds based on 1 year of data from CloudSat and Cloud-Aerosol Lidar and Infrared Pathfinder Satellite Observations (CALIPSO), J. Geophys. Res., 113, D00A14, doi:10.1029/2008JD009835, 2008.

Lilly, D.: Models of cloud-topped mixed layers under a strong inversion, Q. J. Roy. Meteor. Soc., 94, 292-309, 1968.

Ma, C. C., Mechoso, C. R., Robertson, A. W., and Arakawa, A.: Peruvian stratus clouds and the tropical Pacific circulation: A coupled ocean-atmosphere GCM study, J. Climate., 9, 1635-1645, 1996.

McNoldy, B. D., Ciesielski, P. E., Schubert, W. H., and Johnson, R. H.: Surface winds, divergence, and vorticity in stratocumulus regions using QuikSCAT and reanalysis winds. Geophys. Res. Lett., 31, L08105 doi:10.1029/2004GL019768, 2004.

Muñoz, R. C. and Garreaud, R. D.: Dynamics of the low-level jet off the west coast of subtropical South America, Mon. Weather Rev., 133, 3661-3677, 2005.

Myhre, G., Stordal, F., Johnsrud, M., Kaufman, Y. J., Rosenfeld, D., Storelvmo, T., Kristjansson, J. E., Berntsen, T. K., Myhre, A., and Isaksen, I. S. A.: Aerosol-cloud interaction inferred from MODIS satellite data and global aerosol models, Atmos. Chem. Phys., 7, 3081-3101, doi:10.5194/acp-7-3081-2007, 2007.

O’Dell, C. W., Wentz, F. J., and Bennartz, R.: Cloud liquid water path from satellite-based passive microwave observations: A new climatology over the global oceans, J. Climate., 21, 1721-1739, 2008.

Painemal, D. and Zuidema, P.: Synoptically-induced variability in the microphysical properties of the South East Pacific stratocumulus deck, Atmos. Chem. Phys. Discuss., 9, 25523-25564, doi:10.5194/acpd-9-25523-2009, 2009.

Painemal, D., Garreaud, R. G., Rutllant, J., and Zuidema, P.: Southeast Pacific Stratocumulus: High Frequency Variability and Meso-scale Structures over San Félix Island, J. Appl. Meteorol. Clim., 49, 463-477, 2009. 
Rahn, D. A. and Garreaud, R. D.: Marine boundary layer over the subtropical southeast Pacific during VOCALS-REx - Part 2: Synoptic variability, Atmos. Chem. Phys., 4507-4519, doi:10.5194/acp-10-4507-2010, 2010.

Richter, I. and Mechoso, C. R.: Orographic influences on subtropical stratocumulus, J. Atmos. Sci., 63, 2585-2601, 2006.

Rutllant, J. A. and Garreaud, R. D.: Episodes of Strong Flow down the Western Slope of the Subtropical Andes, Mon. Weather Rev., 132, 611-622, 2004.

Rutllant, J. A., Rosenblutha, B., and Hormazabal, S.: Intraseasonal variability of wind-forced coastal upwelling off central Chile (30 S), Cont. Shelf Res., 24, 789-804, 2004.

Serpetzoglou, E., Albrecht, B., Kollias, P., and Fairall, C. W.: Boundary layer, cloud, and drizzle variability in the southeast Pacific stratocumulus regime, J. Climate, 21, 6191-6214, 2008.

Skamarock, W. C., Klemp, J. B., Dudhia, J., Gill, D. O., Barker, D. M., Wang, W., and Powers, J. G.: A description of the advanced research WRF version 2, Tech rep., NCAR, 88 pp., 2005.

Stephens, G.: Cloud feedbacks in the climate system: A critical review, J. Climate, 18, 237-273, 2005.

Tomlinson, J. M., Li, R., and Collins, D. R.: Physical and chemical properties of the aerosol within the southeastern $\mathrm{Pa}$ cific marine boundary layer, J. Geophys. Res., 112, D12211, doi:10.1029/2006JD007771, 2007.

Whelan, S. P., Lord, J., Galbraith, N., and Weller, R., and coauthors: Stratus 9/VOCALS ninth setting of the stratus ocean reference station \& VOCALS regional experiment, Woods Hole Oceanographic Institution, Tech. Report, 127 pp., 2009.
Wood, R. and Bretherton, C. S.: Boundary layer depth, entrainment, and decoupling in the cloud-capped subtropical and tropical marine boundary layer, J. Climate, 17, 3576-3588, 2004.

Wood, R., Bretherton, C., Huebert, B., Mechoso, C. R., and Weller, R., and et al.: VOCALS Regional Experiment: Scientific program overview, available online at: http://www.atmos.washington.edu/ robwood/VOCALS/ VOCALS_SPO_Complete.pdf, 2006

Wood, R., Bretherton, C., Fairall, C., et al.: VOCALS Regional Experiment: Experimental design overview, available online at: http://www.atmos.washington.edu/ robwood/VOCALS/ VOCALS_EDO_Revised_April07.pdf, 2007

Wood, R., Köhler, M., Bennartz, R., and O'Dell, C.: The diurnal cycle of surface divergence over the global oceans, Q. J. Roy. Meteor. Soc., 135, 1484-1493, 2009.

Wyant, M. C., Wood, R., Bretherton, C. S., Mechoso, C. R., Bacmeister, J., Balmaseda, M. A., Barrett, B., Codron, F., Earnshaw, P., Fast, J., Hannay, C., Kaiser, J. W., Kitagawa, H., Klein, S. A., Köhler, M., Manganello, J., Pan, H.-L., Sun, F., Wang, S., and Wang, Y.: The PreVOCA experiment: modeling the lower troposphere in the Southeast Pacific, Atmos. Chem. Phys. Discuss., 9, 23909-23953, doi:10.5194/acpd-9-23909-2009, 2009.

Zuidema, P., Painemal, D., de Szoeke, S., and Fairall, C.: Stratocumulus cloud-top height estimates and their climatic implications, J. Climate, 22, 4652-4666, 2009. 